\section{Campylobacter spp. isolates of swine feces submitted to transport stress: species and antimicrobial resistance}

\author{
Campylobacter spp. isolados de fezes de suínos submetidos a \\ estresse de transporte: espécies e resistência antimicrobiana
}

Roberta Torres de Melo', Mônica Ribeiro Gabriel², Eliane Pereira Mendonça³ , Jéssica Laura Miranda Peixoto4, Guilherme Paz Monteiro ${ }^{5}$, Phelipe Augusto Borba Martins Peres ${ }^{6}$, Edson Campos Valadares Junior ${ }^{7}$ \& Daise Aparecida Rossi ${ }^{8}$

'Veterinary, Dr. Núcleo de Saúde Pública, Faculdade de Medicina Veterinária, Universidade Federal de Uberlândia - UFU, Uberlândia, MG, Brasil

Veterinary, MSc. Laboratório de Epidemiologia Molecular, Faculdade de Medicina Veterinária, Universidade Federal de Uberlândia - UFU, Uberlândia, MG, Brasil

${ }^{3}$ Veterinary, Dr. Laboratório de Biologia Molecular, Faculdade de Medicina Veterinária, Universidade de Uberaba - UNIUBE, Uberaba, MG, Brasil

${ }^{4}$ Veterinary. Laboratório de Epidemiologia Molecular, Faculdade de Medicina Veterinária, Universidade Federal de Uberlândia - UFU, Uberlândia, MG, Brasil

${ }^{5}$ Biologist, MSc. Laboratório de Epidemiologia Molecular, Programa de Pós-graduação em Ciências Veterinárias, Universidade Federal de Uberlândia - UFU, Uberlândia, MG, Brasil

${ }^{6}$ Biologist. Laboratório de Epidemiologia Molecular, Programa de Pós-graduação em Ciências Veterinárias, Universidade Federal de Uberlândia - UFU, Uberlândia, MG, Brasil

`Veterinary. Laboratório de Epidemiologia Molecular, Programa de Pós-graduação em Ciências Veterinárias, Universidade Federal de Uberlândia - UFU, Uberlândia, MG, Brasil

\&Veterinary, Dr. Laboratório de Epidemiologia Molecular, Programa de Pós-graduação em Ciências Veterinárias, Universidade Federal de Uberlândia - UFU, Uberlândia, MG, Brasil

\begin{abstract}
The influence of transport stress in the presence of Campylobacter spp. and the antimicrobial resistance profile were evaluated in feces of 60 pigs. The samples were collected at the finishing farm and after transport to the slaughterhouse, totaling 120 samples. Isolation was performed by plaque culture and identification of the species was obtained by biochemical tests confirmed with the PCR technique. Campylobacter spp. was isolated in $63.3 \%$ of the collected samples at the farm and $91.6 \%$ at the slaughterhouse, evidencing the influence of transport stress on the increase of the isolates ( $\mathrm{P}<0.05$ ). The species $C$. colibiotype I, $C$. jejuni biotype I and C. jejuni subsp. doylei were identified, with $C$. coli being more prevalent on the farm and C. jejuni in the slaughterhouse. Bacterial resistance was observed for all six classes of antibiotics tested. Among them, the isolates presented greater resistance to lincomycin, tetracycline and nalidixic acid (98.9\%), and greater sensitivity to amoxicillin (22.5\%). The strains of $C$. coli showed higher antimicrobial resistance than those of $C$. jejuni $(\mathrm{P}<0.05)$. The results of this study point to the high isolation rates of C. coli and C. jejuni in pig feces destinated for slaughter and possible risks related to meat consumption. The high standards of resistance address the risk to public health.
\end{abstract}

Keywords: antibiotics, campylobacteriosis, feces, swine breeding.

\section{Resumo}

Avaliou-se a influência do estresse de transporte na presença de Campylobacter spp. em fezes suínas de 60 animais sua resistência aos antimicrobianos. As coletas foram realizadas na granja de terminação e após o transporte ao abatedouro, totalizando 120 amostras. O isolamento foi realizado pelo cultivo em placa e a identificação das espécies obtida por testes bioquímicos e PCR. Campylobacter spp. foi isolado de 63,3\% das amostras coletadas na granja e 91,6\% no abatedouro, evidenciando a influência do estresse de transporte no aumento da isolamentos $(\mathrm{P}<0,05)$. Foram identificadas as espécies $C$. coli biótipo I, C. jejuni biótipo I e $C$. jejuni subsp. doylei, sendo que $C$. coli foi mais prevalente na granja e $C$. jejuni no abatedouro. Foi observada resistência bacteriana para todas as seis classes de antibióticos testados. Dentre estes, os isolados apresentaram maior resistência à lincomicina, tetraciclina e ácido nalidíxico (98,9\%), e maior sensibilidade à amoxacilina (22,5\%). As cepas de $C$. coli apresentaram maior resistência antimicrobiana que as de $C$. jejuni $(\mathrm{P}<0,05)$. Os resultados deste estudo alertam para os altos índices de isolamento de
How to cite: Melo, R. T., Gabriel, M. R., Mendonça, E. P., Peixoto, J. L. M., Monteiro, G. P., Peres, P. A. B. M., Valadares Junior, E. C., \& Rossi, D. A. (2019). Campylobacter spp. isolates of swine feces submitted to transport stress: species and antimicrobial resistance. Brazilian Journal of Veterinary Medicine, 41, e086519. http://dx.doi. org/10.29374/2527-2179.bjvm086519

Financial support: CNPq, FAPEMIG e Capes.

Conflict of interests: No conflict of interests declared concerning the publication of this article.

Received: February 02, 2018

Accepted: August 30, 2018.

The study was carried out at Laboratório de Epidemiologia Molecular e Laboratório de Biotecnologia Animal e Aplicada, Uberlândia, MG, Brasil.

\section{*Correspondence}

Roberta Torres de Melo

Faculdade de Medicina Veterinária, Universidade Federal de Uberlândia - UFU Rua Ceará s/n, Bloco 2D sala 43, Campus Umuarama

CEP 38408-018 - Uberlândia (MG), Brasil

E-mail: roberta-melo@hotmail.com

Copyright Melo et al. This is an Open Access article distributed under the terms of the Creative Commons Attribution Non-Commercial License which permits unrestricted non-commercial use, distribution, and reproduction in any medium provided the original work is properly cited. 
C. coli e C. jejuni em fezes de suínos destinados ao abate e possíveis riscos relacionados ao consumo da carne. Os altos padrões de resistência atentam para o risco à saúde pública.

Palavras-Chave: antibióticos, campilobacteriose, fezes, suinocultura.

\section{Introduction}

The Brazilian swine breeding occupy a prominent position on the world stage, as the fourth largest producer and the fourth largest exporter of pork. The production of pork in the country in 2016 showed a percentage increase of $2.42 \%$ compared to the previous year, producing 3.73 million tons of pork (Associação Brasileira de Proteína Animal, 2017).

Given the importance of the country in the sector, there is a need for special care in relation to food safety to ensure the sanitary quality of food. Providing safe food to consumers is a major challenge, and its neglect can lead to the growth of micro-organisms that cause serious infections and poisoning, such as campylobacteriosis, that can lead from simple intestinal discomfort to neurological disorders and death (Miranda \& Barreto, 2012).

Campylobacter is highlighted as one of the main causers of food-borne human gastroenteritis in the world (World Health Organization, 2013). Pigs may be reservoirs for Campylobacter spp. acting as a potential biological contaminant in foods of animal origin (Haruna et al., 2013). Infection in humans occurs through direct contact with carrier animals, through ingestion of raw or poorly processed meat from poultry, swine and cattle or untreated or contaminated feces containing the pathogen (Food and Drug Administration, 2008).

In a study on the prevalence of Campylobacter spp. in pig feces, Burrough et al. (2013) pointed out that $82.6 \%$ of the collected samples were positive for this pathogen. A study conducted in Brazil by Silva et al. (2012) in samples of feces and pig carcasses showed that Campylobacter coli was the most prevalent species in swine.

Animal exposure at all stages of production from farm to slaughter may be an important factor in Campylobacter infection of pigs (Castillo Neyra et al., 2012). The knowledge of the predisposing factors for contamination and their impact along the production chain allows the introduction of control measures in the production process, which is an alternative to guarantee the safety of the food produced. The aim of this study was to determine the isolation of Campylobacter spp. in pig feces before and after transport stress (from finishing farm to slaughterhouse), the diversity of isolated species and their antimicrobial susceptibility profile.

\section{Material and Methods}

The study was performed in a pig finishing farm and in a slaughterhouse under federal inspection located in the region of Triângulo Mineiro, Minas Gerais, Brazil. A total of 120 fecal samples were collected through rectal swab.

The evaluated animals came from a farm located approximately $200 \mathrm{~km}$ from the slaughterhouse, being transported during the night. The period of animals transportation was approximately three hours and the time between arrival at the slaughterhouse and the collection was approximately one hour.

The collections were done in 60 animals in the finishing farm and in these same animals after transportation to the slaughterhouse and already settled in the waiting pen. The collections were divided into three different batches of 20 animals in the finishing phase (age of 138 - 140 days) and with an average weight of $90 \mathrm{~kg}$.

For transport, the swabs were kept in transport medium ( $5 \mathrm{~mL}$ of sterile buffered peptone water) and sent immediately to the laboratory. For isolation of Campylobacter spp. and biochemical identification, the protocol of analysis used was the traditional cultivation in plates with pre-enrichment, according to recommendations of Fernández (2011) with modifications according to ISO 10272-1 (International Organization for Standardization, 2006).

Pre-enrichment was based on the addition of a $2.5 \mathrm{~mL}$ aliquot of sterile buffered peptone water with 2.5mL of Bolton broth $\left(\mathrm{Oxoid}^{\circledR}\right)$ supplemented with antibiotic mixture (10mg of cefoperazone, $10 \mathrm{mg}$ of vancomycin, 10mg of trimethoprim and 25mg of cycloheximide) (Selective Supplement Oxoid $^{\circledR}$ ), both in double concentration and added with $5 \%$ of hemolyzed equine blood, incubated 
under a microaerophilic atmosphere (Probac do Brasil ${ }^{\circledR}$ ) at $37^{\circ} \mathrm{C}$ for 4 to 6 hours and $41.5^{\circ} \mathrm{C}$ for 44 hours \pm 4 hours.

The pre-enriched broth was seeded on Campylobacter Blood-Free Selective Medium (modified CCDA) agar (Oxoid ${ }^{\circledR}$ ) with antibiotic supplement (16mg of cefoperazone and $32 \mathrm{mg}$ of amphotericin B) (Oxoid ${ }^{\circledR}$ ) and incubated at $41.5^{\circ} \mathrm{C}$ for 44 hours \pm 4 hours in microaerophilia (Probac do Brasil ${ }^{\circledR}$ ). Colonies suspected of belonging to the genus Campylobacter were confirmed by modified Gram staining (use of carboxifuccin replacing safranin) and species were identified by catalase, oxidase, sulfide production (H2S), nitrate reduction (NO3), hippura hydrolysis and DNAse test (for biotyping) (Fernández, 2011).

Campylobacterjejuni (ATCC 33291), Campylobacter coli (ATCC 43478) and a Campylobacter jejuni strain (IAL 2383) isolated from humans were used as controls.

Identification by molecular polymerase chain reaction (PCR) was performed in parallel with the traditional identification methodology for confirmation of C. jejuni positive strains in biochemical tests. The primers and the protocol used in the reaction and amplification were followed according to Hänel et al. (2004). The primers used for identification of $C$. jejuni comprise the flaA gene: flaA-F (5'ATGGGATTTCGTATTAACAC3') and flaA-R (5' CTGTAGTAATCTTAAAACATTTTG3').

The final volume for the amplification reaction was $50 \mu \mathrm{L}$, composed of $20 n g$ of the bacterial DNA solution (extracted by the Wizard ${ }^{\circledR}$ Genomic DNA Purification kit - Promega ${ }^{\circledR}$ ) and by the following reagents: $10 \mathrm{mM}$ of Tris-HCL; $50 \mathrm{mM}$ of $\mathrm{KCl} ; 200 \mu \mathrm{M}$ of each triphosphate deoxynucleotide (DNTP); $5.5 \mathrm{mM}$ of $\mathrm{MgCl}_{2} ;$ 2Opicomoles of flaA-F and flaA-R and 1.25U of Taq DNA polymerase.

The thermocycler amplification (Eppendorf ${ }^{\circledR}$ ) obeyed the following cycles: an initial denaturation cycle at $94^{\circ} \mathrm{C}$ for 4 minutes; 25 amplification cycles consisting of 3 stages: denaturation at $94{ }^{\circ} \mathrm{C}$ for one minute, annealing at $47^{\circ} \mathrm{C}$ for one minute and extension at $72^{\circ} \mathrm{C}$ for one minute; completing with another final extension cycle at $72^{\circ} \mathrm{C}$ for 7 minutes. The volume of $5 \mu \mathrm{L}$ of the amplification products were subjected to $1.5 \%$ agarose gel electrophoresis stained with Syber Safe $\left(\right.$ Invitrogen ${ }^{\circledR}$ ), using as a molecular weight standard the 100bp marker (Invitrogen ${ }^{\circledR}$ ).

For the evaluation of antimicrobial resistance, the disc diffusion test was used with addition of $5 \%$ of defibrinated goat blood (Laborclin ${ }^{\circledR}$ ) to Mueller-Hinton agar (Difco ${ }^{\mathrm{TM}}$ ) and incubation in a microaerophilic atmosphere at $37^{\circ} \mathrm{C}$ per 48 hours (Clinical and Laboratory Standards Institute, 2010). The antimicrobials tested were: nalidixic acid (30 $\mu \mathrm{g})$, amoxicillin $(10 \mu \mathrm{g})$, erythromycin $(15 \mu \mathrm{g})$, gentamicin $(10 \mu \mathrm{g})$, lincomycin $(9 / 100 \mu \mathrm{g})$, neomycin $(30 \mu \mathrm{g})$, norfloxacin $(10 \mu \mathrm{g})$ and tetracycline $(30 \mu \mathrm{g})$.

The results were submitted to descriptive statistics, with the calculation of the percentages of isolation and antimicrobial resistance. In order to compare the different proportions of positivity of the batches, the McNemar Test with a significance of 5\% was used (Ayres et al., 2000). The confidence limits for the analysis of differences in the resistance ratios of $C$. coli and C. jejuni were established through the Binomial Proportions test with 95\% of confidence. Calculations were performed using the GraphPadPrism program.

\section{Results}

The percentage of Campylobacter spp. in feces samples from the farm was 63.3\% (38/60) and 91.6\% (55/60) after transportation at the slaughterhouse.

There was a significant difference between the groups before and after transport $(\mathrm{P}<0.05)$ indicating that the stress period may influence the increase in the excretion rate of the microorganism, resulting in an increase in the number of isolates as presented in Table 1.

Campylobacter coli biotype I was identified in 53 (57.0\%) samples (33 from the farm and 20 from the slaughterhouse), Campylobacter jejuni biotype I in 20 (21.5\%) samples (five from the farm and 15 from the slaughterhouse) and Campylobacter jejuni subspecie doylei in 20 (21.5\%) samples from the slaughterhouse.

In the samples collected after transport to the slaughterhouse there was isolation of $C$. jejuni subspecie doylei, which was not previously identified in the animals settled in the termination farm, probably because it was present in an amount insufficient to be detected by the traditional method used. 
Table 1. Positivity to Campylobacter spp. in feces samples collected on the farm and at the slaughterhouse in three different batches of finishing pigs.

\begin{tabular}{lcccc}
\hline \multicolumn{1}{c}{$\begin{array}{c}\text { SAMPLES / } \\
\text { COLLECTION POINT }\end{array}$} & $\begin{array}{c}\text { Batch A } \\
\mathbf{( n = 2 0 )}\end{array}$ & $\begin{array}{c}\text { Batch B } \\
\mathbf{( n = 2 0 )}\end{array}$ & $\begin{array}{c}\text { Batch C } \\
\mathbf{( n = 2 0 )}\end{array}$ & $\begin{array}{c}\text { Total } \\
(\mathbf{n}=\mathbf{6 0})\end{array}$ \\
\cline { 2 - 5 } & $\mathbf{+ ( \% )}$ & $+\mathbf{( \% )}$ & $\mathbf{+ ( \% )}$ & $+\mathbf{+ \% )}$ \\
\hline Feces swab/farm & $13(65)$ & $10(50)$ & $15(80)$ & $38(63.3)^{\mathrm{a}}$ \\
Feces swab /slaughterhouse & $16(80)$ & $19(95)$ & $20(100)$ & $55(91.6)^{\mathrm{b}}$ \\
TOTAL (n=120) & $29(72.5)$ & $29(72.5)$ & $35(87.5)$ & $93(77.5)$ \\
\hline
\end{tabular}

+ positive samples; $n$ - number of collected animals; ${ }^{a / b}$ - different letters in the same column indicate that there was significant difference by the McNemar Test ( $P<0.05$ - probability of significance).

Table 2. Distribution and antibiotic resistance profile of strains of $C$. coli and C. jejuni, isolated from feces of pigs settled on the farm and at the slaughterhouse pen.

\begin{tabular}{|c|c|c|c|c|c|c|}
\hline \multirow{3}{*}{ Antibiotics } & \multicolumn{2}{|c|}{ Farm $(n=38)$} & \multicolumn{2}{|c|}{ Slaughterhouse $(\mathrm{n}=55)$} & \multicolumn{2}{|c|}{ Total $(\mathrm{n}=93)$} \\
\hline & $\begin{array}{l}\text { C. coli } \\
(\mathrm{n}=33)\end{array}$ & $\underset{(\mathrm{n}=5)}{\text { C. jejuni }}$ & $\begin{array}{c}\text { C. coli } \\
(\mathrm{n}=20)\end{array}$ & $\begin{array}{c}\text { C. jejuni } \\
(\mathrm{n}=35)\end{array}$ & $\begin{array}{l}\text { C. coli } \\
(\mathrm{n}=53)\end{array}$ & $\begin{array}{c}\begin{array}{c}\text { C. jejuni } \\
(\mathrm{n}=40)\end{array}\end{array}$ \\
\hline & $\mathrm{R}(\%)$ & $\mathrm{R}(\%)$ & $\mathrm{R}(\%)$ & $\mathrm{R}(\%)$ & $\mathrm{R}(\%)$ & $\mathrm{R}(\%)$ \\
\hline Nalidixic Acid & $32(96.97)$ & $5(100)$ & $20(100)$ & $35(100)$ & $52(98.11)$ & $40(100)$ \\
\hline Amoxicillin & $8(24.24)$ & 0 & $6(30)$ & $7(20)$ & $14(26.41)$ & $7(17.5)$ \\
\hline Erythromycin & $33(100)$ & $5(100)$ & $18(90)$ & $30(85.71)$ & $51(96.23)$ & $35(87.5)$ \\
\hline Gentamicin & $26(78.79)$ & 0 & $6(30)$ & $16(45.71)$ & $32(60.38)^{*}$ & $16(40)^{*}$ \\
\hline Lincomycin & $33(100)$ & $5(100)$ & $19(95)$ & $35(100)$ & $52(98.11)$ & $40(100)$ \\
\hline Neomycin & $26(78.79)$ & $1(20)$ & $16(80)$ & $17(48.57)$ & $42(79.24)^{*}$ & $18(45)^{*}$ \\
\hline Norfloxacin & $26(78.79)$ & $5(100)$ & $12(60)$ & $29(82.86)$ & $38(71.7)$ & $34(85)$ \\
\hline Tetracycline & $33(100)$ & $5(100)$ & $19(95)$ & $35(100)$ & $52(98.11)$ & $40(100)$ \\
\hline
\end{tabular}

R - number of resistant strains; \% - percentage of resistance; $n$ - number of isolates; ${ }^{*}$ - significant difference $(P<0.05)$.

The results presented by PCR confirmed the presence of Campylobacter jejuni in the samples previously identified in the biochemical tests.

Resistance was observed to all eight antibiotics tested, distributed in six classes (Table 2). Most of the strains tested (72/93 - 77.4\%) showed multiresistance characteristics, as they showed resistance to three or more antimicrobial classes (Magiorakos et al., 2012). Among the antibiotics tested, the isolates presented higher resistance to lincomycin (lincosamides), tetracycline (tetracycline) and nalidixic acid (fluoroquinolone) (92/93 - 98.9\%), followed by erythromycin (macrolide) (83/93 - 92. 4\%), norfloxacin (fluoroquinolone) (72/93 - 77.4\%), neomycin (aminoglycoside) (60/93 - 64.5\%), gentamicin (aminoglycoside) (48/93 - 51.6\%) and amoxicillin (beta-lactam) (21/93 - 22.5\%).

The antibiotic resistance was compared between C. jejuni and C. coli isolates (Table 2). There was a significant difference between the two species, with $C$. coli presenting higher resistance than C. jejuni for gentamicin ( $\mathrm{P}=0.0258)$ and neomycin $(\mathrm{P}=0.0003)$.

\section{Discussion}

The high percentage of Campylobacter isolation was expected, considering the literature findings. Campylobacter spp. were found by Matthew-Belmar et al. (2015), Gwimi et al. (2015), Wysok et al. (2015), equivalent to 95.6\% (172/180), 92.67\% (278/300) and 29.8\% (52/174), respectively, in pig feces samples. 
In Brazil, C. coli and C.jejuni have been isolated from carcasses and feces of apparently healthy pigs abated in slaughterhouses, as well as from animals with clinical symptoms of enteric disorders manifested as diarrhea (Scarcelli et al., 1991; Gabriel et al., 2010; Silva et al., 2012).

The increase in the number of animals excreting Campylobacter proved that there is a possibility of the influence of transport stress on the increase of excretion of the agent and consequent infection of the animals. Harvey et al. (2001) found that transport of pigs may affect the prevalence of Campylobacter spp. under conditions of high temperatures and prolonged fasting. According to the same authors besides the increase in the number of infected animals there was also an increase in the amount of Campylobacter spp. with a variation of 5 to $7.2 \log 10 \mathrm{CFU} / \mathrm{g}$, due to increased of cecal $\mathrm{pH}$, which reduces bacterial competition and allows Campylobacter spp. to proliferate more quickly, data also analyzed by the authors.

Alter et al. (2005) that found a prevalence of Campylobacter spp. in 24-week-old pigs, ranging from zero on the farm to $78 \%$ after transporting the animals to the slaughterhouse.

According to Dalla Costa et al. (2010) pigs submitted to transport present at the end of the journey obvious symptoms of stress. The differences in the way that animals deal with stress are reflected in the immunological reactivity that may be reduced in order to facilitate the proliferation of enteric bacteria and their consequent spread in the environment (Tizard Ian, 2014).

Pigs are often asymptomatic carriers of Campylobacter spp. and this carrier status may increase the likelihood of contamination of carcasses during the slaughter process (Malakauskas et al., 2005). Studies by Rosenvold \& Andersen (2003) have added that stress during transport is considered a favorable factor in the excretion of pathogenic microorganisms in production animals, corroborating the increase of the isolates after transport.

It is known that the greater amount of microorganisms in the sample raises the chances of their isolation in traditional methods of cultivation. Therefore, the increase in the number of isolates at the moment after transport to the slaughterhouse reflects the greater quantity and probability of contamination of the carcasses during the slaughter process, being this information relevant to the pathogen reduction / prevention policies in the industry.

Although there is still no legislation to control the microorganism in pork, the presence of Campylobacter began to be quantified in chicken carcasses in southern Brazil at the request of the European Union (União Europeia, 2017). Given that pork can also be a source of human campylobacteriosis, it is possible that in future importing countries will also extend the requirements for pork.

Among the species identified and unlike birds and cattle, Campylobacter coli was the most prevalent species on the farm. Silva et al. (2012), Haruna et al. (2013), Gwimi et al. (2015), also reported a higher prevalence of $C$. coli compared to C. jejuni in their findings. Alter et al. (2005) reported that Campylobacter coli can colonize 75\% of piglets in the first week of life, and it is possible that this strain is part of the microbiota of these animals.

The isolation of $C$. jejuni biotype I and subsp. doylei of the samples collected after transport to the slaughterhouse probably indicates that they were already part of the faecal microbiota of these animals, in small numbers, and that factors such as stress or fasting were able to favor their multiplication to numbers identifiable by the techniques used.

The use of biochemical tests to identify the species of Campylobacter is limited by the occurrence of strains with atypical reactions. Small alterations in the amount of the inoculum, excessive subcultures, deletions of the hip gene and absence of its transcription can interfere in the correct identification of the species (Kolackova \& Karpiskova, 2005). Although 100\% of concordance was observed in the identification of $C$. jejuni by biochemical identification and PCR, the use of a genotypic identification method is useful for the rapid results and can be used in the case of strains with atypical responses in the identification phenotype.

The resistance identified for all antimicrobials indicates the difficulty in treatment in case of clinical disease in humans. Haruna et al. (2013) reported that resistance to these antimicrobial agents (nalidixic acid, enrofloxacin, oxytetracycline and dihydrostreptomycin) has already been observed in Campylobacter isolates obtained from pig feces samples. Resistance to antibiotics is relevant information, since campylobacteriosis is a disease transmitted primarily by the consumption of contaminated foods, particularly those of animal origin. 
The results of this study are similar to the findings of Fraqueza et al. (2014) who observed high resistance to fluoroquinolone, tetracycline and macrolides and sensitivity to gentamicin and amoxaciclin in Campylobacter spp. in pigs. Sasaki et al. (2013) observed resistance in Campylobacter spp. collected from porcine liver to nalidixic acid, dihydrostreptomycin and oxytetracycline. Nguyen et al. (2016) found resistance to nalidixic acid, tetracycline and ciprofloxacin in percentages of $88.9 \%, 77.8 \%$ and $66.7 \%$, respectively, in samples from chicken and pork meat.

Thakur \& Gebreyes (2005) tested six antibiotics in C. colistrains isolated from an antimicrobial-free pig production system. The antibiotics, to which $97 \%$ of the microorganisms tested presented higher resistance, were: erythromycin, nalidixic acid and tetracycline. Ekkapobyotin et al. (2008) also found similar values when analyzing strains of $C$. coli isolated from swine. The strains had high levels of resistance to nalidixic acid (84\%), tetracycline (81\%) and erythromycin (66\%).

The fact that $C$. coli has higher antimicrobial resistance when compared to $C$. jejuni has already been described by other authors. Pezzotti et al. (2003) in a study on the occurrence of $C$. coli and C. jejuni in cattle, pigs and chickens, compared antimicrobial resistance between the two species and concluded that $C$. coli was more resistant than $C$. jejuni, with tetracycline and streptomycin being the antibiotics with the greatest divergence. Little et al. (2008) also found resistance of $C$. coli to antibiotics: ampicillin, chloramphenicol, tetracycline, furazolidone, gentamicin, kanamycin, neomycin, nalidixic acid, ciprofloxacin and erythromycin.

The resistance patterns observed for antimicrobials of the macrolide (erythromycin) and fluoroquinolones (nalidixic acid and norfloxacin) classes are difficult to treat in case of infection, since they are drugs of choice for the treatment of campylobacteriosis (Ternhag et al., 2007). The increased occurrence of macrolide and fluoroquinolone-resistant infections in man has been reported in several countries (Thakur \& Gebreyes, 2005; Ekkapobyotin et al., 2008; Fraqueza et al., 2014).

The routine practice of providing antibiotics to animals on farms for both prevention and therapy is an important factor in the emergence of bacterial resistance to antibiotics and can therefore be transferred to humans through the food chain (Angulo et al., 2000).

Due to the common appearance of pathogens that express multiresistance, there is an increase in cases of mortality in bacterial diseases, complications in treatments, and costs for the health system. The prudent use of antimicrobials, appropriate choice, dosage and appropriate duration helps to reduce the selective pressure of resistant microorganisms (Tenover, 2006).

\section{Conclusion}

There was a significant increase in the isolates of Campylobacter spp. in feces of finishing pigs evaluated after stress of transport of the animals to the slaughterhouse, which may reflect in the contamination of the carcasses during the slaughter. The identified species: $C$. coli biotype I, C. jejuni biotype I and C. jejuni subsp. doylei are etiological agents of human campylobacteriosis demonstrating that the findings are relevant to public health. Most of the strains studied presented a multiresistance profile to the antimicrobials, with amoxicillin being the drug indicated as the most effective for the studied species.

\section{References}

Alter, T., Gaull, F., Kasimir, S., Gürtler, M., Mielke, H., Linnebur, M., \& Fehlhaber, K. (2005). Prevalences and transmission routs of Campylobacter spp. strains within multiple pig farms. Veterinary Microbiology, 108(3-4), 251-261. http://dx.doi.org/10.1016/j.vetmic.2005.03.004. PMid:15885928.

Angulo, F. J., Johnson, K., Tauxe, R., \& Cohen, M. L. (2000). Origins and consequences of antimicrobial-resistant nontyphoidal Salmonella: implications for the use of fluoroquinolones in food animals. Microbial Drug Resistance, 6(1), 77-83. http://dx.doi.org/10.1089/mdr.2000.6.77. PMid:10868811.

Associação Brasileira de Proteína Animal. (2017). Relatório anual. Retrieved in 2018, January 10, from http:// abpa-br.com.br/setores/avicultura/publicacoes/relatorios-anuais

Ayres, M., Ayres Junior, M., Ayres, D. L., Santos, A.S. (2000). BioEstat 2.O: Aplicações estatísticas nas áreas das ciências biológicas e médicas. Belém: Sociedade Civil Mamirauá; Brasília: CNPq.

Burrough, E., Terhorst, S., Sahin, O., \& Zhang, Q. (2013). Prevalence of Campylobacter spp. relative to other enteric pathogens in grow-finish pigs with diarrhea. Anaerobe,22,111-114. http://dx.doi.org/10.1016/j.anaerobe.2013.06.004. PMid:23792232. 
Castillo Neyra, R., Vegosen, L., Davis, M. F., Price, L., \& Silbergeld, E. K. (2012). Antimicrobial-resistant Bacteria: an unrecognized work-related risk in food animal production. Safety and Health at Work, 3(2), 85-91. http:// dx.doi.org/10.5491/SHAW.2012.3.2.85. PMid:22993711.

Clinical and Laboratory Standards Institute. (2010). Methods for antimicrobial dilution and disk susceptibility testing of infrequently isolated or fastidious bacteria (2nd ed. M45-A2, Vol. 30, No. 18). Wayne: CLSI.

Dalla Costa, O. A., Ludke, J. V., Costa, M. J. R. P., Faucitano, L., Peloso, J. V., \& Dalla Roza, D. (2010). Efeito das condições pré-abate sobre a qualidade da carne de suínos pesados. Archivos de Zootecnia, 227, 391-402.

Ekkapobyotin, C., Padungtod, P., \& Chuanchuen, R. (2008). Antimicrobial resistance of Campylobacter coli isolates from swine. International Journal of Food Microbiology, 128(2), 325-328. http://dx.doi.org/10.1016/i. ijfoodmicro.2008.09.005. PMid:18945505.

Fernández, H. (2011). Campylobacter y campylobacteriosis:una mirada desde américa del sur. Revista Peruana de Medicina Experimentaly Salud Pública, 28(1), 121-127. http://dx.doi.org/10.1590/S1726-46342011000100019. PMid:21537780.

Food and Drug Administration. (2008). Campylobacter jejunibad bug book. Retrieved in 2018, January 10. from https://www.fda.gov/food/foodborneillnesscontaminants/causesofillnessbadbugbook/

Fraqueza, M. J., Martins, A., Borges, A. C., Fernandes, M. H., Fernandes, M. J., Vaz, Y., Bessa, R. J. B., \& Barreto, A. S (2014). Antimicrobial resistance among Campylobacter spp. strains isolated from different poultry production systems at slaughterhouse level. Poultry Science, 93(6), 1578-1586. http://dx.doi.org/10.3382/ps.2013-03729. PMid:24879708.

Gabriel, M. R., Melo, R. T., Rossi, D. A., \& Belchiolina, B. F. (2010). Campylobacter spp. em linfonodos mesentéricos de suínos abatidos. PUBVET, 4(19).

Gwimi, P. B., Faleke, O. O., Salihu, M. D., Magaji, A. A., Abubakar, M. B., Nwankwo, I. O., \& Ibitoye, E. B. (2015) Prevalence of Campylobacter species in fecal samples of pigs and humans from Zuru Kebbi State, Nigeria. International Journal of One Health, 1, 1-5. http://dx.doi.org/10.14202/IJOH.2015.1-5.

Hänel, I., Muller, J., Muller, W., \& Schulze, E. (2004). Correlation between invasion of Caco-2 eukaryotic cells and colonization ability in the chick gut in Campylobacter jejuni. Veterinary Microbiology, 101(2), 75-82. http:// dx.doi.org/10.1016/j.vetmic.2004.04.004. PMid:15172689.

Haruna, M., Sasaki, Y., Murakami, M., Mori, T., Asai, T., Ito, K., \& Yamada, Y. (2013). Prevalence and Antimicrobial Resistance of Campylobacter isolates from beef cattle and pigs in Japan. The Journal of Veterinary Medical Science, 75(5), 625-628. http://dx.doi.org/10.1292/jvms.12-0432. PMid:23220905.

Harvey, R. B., Anderson, R. C., Young, C. R., Swindle, M. M., Genovese, K. J., Hume, M. E., Droleskey, R. E., Farrington, L. A., Ziprin, R. L., \& Nisbet, D. J. (2001). Effects of feed withdrawal and transport on cecal environment and Campylobacter concentrations in a swine surgical model. Journal of Food Protection, 64(5), 730-733. http:// dx.doi.org/10.4315/0362-028X-64.5.730. PMid:11348010.

International Organization for Standardization. (2006). ISO 10272-1. Microbiology of food and animal feeding stuffs - Horizontal method for the detection and enumeration of Campylobacter - Part 1: Detection method (1. ed.). Geneva: ISO.

Kolackova, I., \& Karpiskova, R. (2005). Species level identification of thermotolerant campylobacters. Veterinarni Medicina, 12, 543-547.

Little, C. L., Richardson, J. F., Owen, R. J., de Pinna, E., \& Threlfall, E. J. (2008). Campylobacter and Salmonella in raw red meats in the United Kingdom: Prevalence, characterization and antimicrobial resistance pattern, 2003-2005. Food Microbiology, 25(3), 538-543. http://dx.doi.org/10.1016/j.fm.2008.01.001. PMid:18355680.

Magiorakos, A. P., Srinivasan, A., Carey, R. B., Carmeli, Y., Falagas, M. E., Giske, C. G., Harbarth, S., Hindler, J. F., Kahlmeter, G., Olsson-Liljequist, B., Paterson, D. L., Rice, L. B., Stelling, J., Struelens, M. J., Vatopoulos, A., Weber, J. T., \& Monnet, D. L. (2012). Multidrug-resistant, extensively drug-resistant and pandrug-resistant bacteria: an international expert proposal for interim standard definitions for acquired resistance. Clinical Microbiology and Infection, 18(3), 268-281. http://dx.doi.org/10.1111/j.1469-0691.2011.03570.x. PMid:21793988.

Malakauskas, M., Jorgensen, K., Nielsen, E. M., Ojeniyi, B., \& Olsen, J. E. (2005). Isolation of Campylobacter spp. from a pig slaughterhouse and analysis of cross-contamination. International Journal of Food Microbiology, 108(3), 295-300. PMid:16556467.

Matthew-Belmar, V., Amadi, V. A., Stone, D., Subbarao, C., DeAllie, C., Sharma, R., \& Hariharan, H. (2015). Antimicrobial resistance profiles of Campylobacter jejuni and Campylobacter coli Recovered from Feces of Young Healthy Domestic Pigs in Grenada. International Journal of Current Microbiology and Applied Sciences, 4(10), 197-206.

Miranda, P. C., \& Barreto, N. S. E. (2012). Avaliação higiênico-sanitária de diferentes estabelecimentos de comercialização da carne de-sol no município de Cruz das Almas-BA. Revista Caatinga, 25, 166-172.

Nguyen, T. N. M., Hotzel, H., El-Adawy, H., Tran, H. T., Le, M. T. H., Tomaso, H., Neubauer, H., \& Hafez, H. M. (2016). Genotyping and antibiotic resistance of thermophilic Campylobacter isolated from chicken and pig meat in Vietnam. Gut Pathogens, 8(1), 19. http://dx.doi.org/10.1186/s13099-016-0100-x. PMid:27175218.

Pezzotti, G., Serafin, A., Luzzi, I., Mioni, R., Milan, M., \& Perin, R. (2003). Occurrence and resistance to antibiotics of Campylobacter jejuni and Campylobacter coli in animals and meat in northeastern Italy. International Journal of Food Microbiology, 82(3), 281-287. http://dx.doi.org/10.1016/S0168-1605(02)00314-8. PMid:12593931. 
Rosenvold, K., \& Andersen, H. J. (2003). Factors of significance for pork quality - a review. Meat Science, 64(3), 219-237. http://dx.doi.org/10.1016/S0309-1740(02)00186-9. PMid:22063008.

Sasaki, Y., Haruna, M., Murakami, M., Hayashida, M., Ito, K., Noda, M., \& Yamada, Y. (2013). Prevalence of Campylobacter spp., Salmonella spp., Listeria monocytogenes, and Hepatitis E virus in swine livers collected at an Abattoir. Japanese Journal of Infectious Diseases, 66(2), 161-164. http://dx.doi.org/10.7883/yoken.66.161. PMid:23514917.

Scarcelli, E., Genovez, M. E., Rojas, S., et al (1991). Avaliação da presença de Campylobacter spp em suínos: sua relação com a ocorrência de distúrbios entéricos. Revista de Microbiologia, 22, 112-115.

Silva, G. O., Carvalho, A. F., Miyashiro, S., Nassar, A. F. C., Piatti, R. M., \& Scarcelli, E. (2012). Detecção de fatores de virulência em estirpes de Campylobacter spp. isoladas de carcaças de suínos abatidos em frigoríficos. Arquivo Brasileiro de Medicina Veterináriae Zootecnia, 64(5), 1209-1215. http://dx.doi.org/10.1590/S0102-09352012000500019.

Tenover, F. C. (2006). Mechanims of bacterial resistance in bacteria. The American Journal of Medicine, 119(6), 3-10. http://dx.doi.org/10.1016/j.amjmed.2006.03.011.

Ternhag, A., Asikainen, T., Giesecke, J., \& Ekdahl, K. (2007). A meta-analysis on the effects of antibiotic treatment on duration and symptoms caused by infection with Campylobacter species. Clinical Infectious Diseases, 44(5), 696-700. http://dx.doi.org/10.1086/509924. PMid:17278062.

Thakur, S., \& Gebreyes, W. A. (2005). Prevalence and antimicrobial resistance of Campylobacter in antimicrobialfree and conventional pig production systems. Journal of Food Protection, 68(11), 2402-2410. http://dx.doi. org/10.4315/0362-028X-68.11.2402. PMid:16300080.

Tizard Ian, R. (2014). Imunologia veterinária: uma introdução. (9. ed., 551 p.). Rio de Janeiro: Elsevier.

União Europeia. (2017, 23 de agosto). Regulamento (UE) 2017/1495; altera o Regulamento (CE) n. ${ }^{\circ}$ 2073/2005 no que diz respeito à Campylobacter em carcaças de frangos de carne. Jornal Oficial da União Europeia.

World Health Organization. (2013). The global view of campylobacteriosis. Retrieved in 2018, January 27, from https://extranet.who.int/iris/restricted/bitstream/10665/80751/1/978924156 4601_eng.pdf

Wysok, B., Pastuszczak-Frak, M., Gomółka-Pawlicka, M., Dzisko, J., Dziedziech, M., \& Marko, A. (2015). Prevalence and antimicrobial resistance of Campylobacter spp. strains isolated from slaughter animals and human. Medycyna Weterynaryjna, 71(12), 801-806. 